\title{
Activités
}

\section{Market and regulation of general interest in the passenger land transport sector: a debate renewed by drivers' activity}

Marché et régulation de l'intérêt général dans le secteur du transport routier de passagers : un débat rénové par l'activité des conducteurs Mercado y regulación del interés general en el sector del transporte vial de pasajeros: un debate renovado por la actividad de los conductores

Liliana Cunha and Marianne Lacomblez

\section{OpenEdition}

\section{Journals}

Electronic version

URL: http://journals.openedition.org/activites/1457

DOI: 10.4000/activites.1457

ISSN: $1765-2723$

Publisher

ARPACT - Association Recherches et Pratiques sur les ACTivités

\section{Electronic reference}

Liliana Cunha and Marianne Lacomblez, « Market and regulation of general interest in the passenger land transport sector: a debate renewed by drivers' activity », Activités [Online], 4-1 | avril 2007, Online since 15 April 2007, connection on 19 April 2019. URL : http://journals.openedition.org/activites/1457 ; DOI : 10.4000/activites. 1457

\section{$\Theta \oplus \Theta \Theta$}

Activités est mis à disposition selon les termes de la licence Creative Commons Attribution - Pas d'Utilisation Commerciale - Pas de Modification 4.0 International. 


\title{
Market and regulation of general interest in the passenger land transport sector: a debate renewed by drivers' activity
}

\author{
Liliana Cunha \& Marianne Lacomblez \\ Faculdade de Psicologia e de Ciências da Educação, Universidade do Porto, \\ Rua do Dr. Manuel Pereira da Silva, 4200-392 Porto - Portugal \\ lcunha@fpce.up.pt \\ lacomb@fpce.up.pt
}

\begin{abstract}
This study analyses the working activity of drivers in the passenger land transport sector in the Metropolitan area of Porto. It considers the evolutions that follow a privatization policy and, namely, the changes at the level of work organization and the objectives which regulate this activity. Two cases have been object of a particular attention. In the first case, a bus route was selected on which three companies did business: a public company; anothercompany whichuses therouteunderanalysis as a result of a concession attributed and controlled by the public company; and a third private company. In the second case, only one private bus company operated on the route. The final results of this research suggest that the companies' policies are generally based, essentially, on market oriented options. On the other hand, the drivers try to balance these options with their own choices and solutions, which are based on values without dimension. The contribution of ergology enriched the reflexion on the strategies and renormalizations that workers make everyday, to establish operative tradeoffs which make management of the activity's objectives and the real needs of the users possible.
\end{abstract}

KEYWORDS:

Activity theory, Changes, Driver's activity, Ergologic approach, Values.

\section{1.- Introduction}

During the last years, the bus transport system of Metropolitan Area of Porto, in Portugal, has been undergoing several changes, to try to reverse people's tendencies to use private transportation instead of public transportation.

It was from the 90 s that the private vehicle began to be seen as a competitor to public transport, entirely transforming the mobility system, since in 1991 collective transport held a market share of $42 \%$ as opposed to $23 \%$ for cars. In less than ten years (from 1991 to 2001), these values had changed radically with the relation now being $28 \%$ and $49 \%$, respectively (ANTROP, 2002).

On the other hand, Regulation (EEC) $\mathrm{n}^{\circ} 1893 / 91$, in the same period, legitimised the opening to privatisation and imposed, at a European level, obligations of public service for private companies, aimed at guaranteeing services conforming with determined pricing norms, continuity, regularity and reception capacity. This measure not only brought about an increase in the number of private transport operators, but also demanded a transformation of the exploitation fields being used by each of these companies. 
The objectives pursued by the companies of the sector were being redefined, since if until that time a markedly social orientation had predominated (rendering a transport service with a guarantee to the right to mobility), from then on, other criteria in the rendering of a service started to emerge, related to its economic viability. This change has led to processes of resizing the workforce and adopting new management models, legitimised by the concern to conceive a service considering more the customer and their loyalty to each company in particular (INOFOR, 2000).

With the aim of better understanding these changes, we have analysed driver activity, since it is them who are most directly implicated in these transformations. In fact, in the context of an extremely competitive economy, it is the customer who makes the choice for the best quality service, among the range of services on offer (Gadrey, 1996), and the driver service is therefore considered decisive in "winning over" the customer.

Despite this, the service activity and the conditions in which it is developed have not been focused on the discussion on changes affecting the sector. The most frequently implemented measures have been, above all, at the level of improving infra-structures and technical means, such as: increasing the number of compulsory payment parking spaces, opening bus lanes, traffic lights prioritising public transport and development of new ticketing technologies. But these measures have not been sufficient and it seems necessary to complement them with a closer look at what is going on, within the driver activity itself.

So, we asked ourselves a question: in what way could the analysis of the activity enhance the debate of which it is part; and in what way can it be the anchoring-place for the search of other possible solutions to respond to the challenge of the public transport use?

\section{2.- The analysis of the service activity: an inevitable reference to respond to the challenges of the sector}

The common preoccupation of all those who use ergonomic analysis of the activity does not consist simply of recognising that there is, and that there will always be, nuances, that can not be ignored, between the prescribed work and the real work, but it consists also of exploring the sense that covers that activity, and of understanding its meaning (Noulin, 1995).

The first analyses of the driver activity, in four companies, were determinant in understanding that we can not restrict the service rendered only to its inter-relational dimension; to the relation between the driver and the customer.

It is necessary to consider the conditions to assure the service and, specially, the margin available to respond to the ever more specific requests of the customers.

The predominance of a market logic, in which drivers' activity is nowadays developed, makes the service for the customer, at the same time, an obligation of means rendered and results (commercial relationship) (Flageul-Caroly, 2001). This way, it is possible to verify that situations of heavy traffic or accidents have been the focus of more attention and increasing control, because despite being considered external events to public transport, they contribute to a decrease in the quality of the service.

This concern with controlling unpredictable effects on the service offered - and the will to manage these effects in the least time possible and with the fewest implications on punctuality and in relation to the customer -, is advanced as a justification for the creation of an "outside-the-rules-driver" function. This designation is due to the fact that this category of drivers is not regulated by the same rules as other drivers: their function is to substitute other drivers, whose service was impaired (for example, the bus breaking down or an accident), that's why they do not drive on an exclusive route or at a predefined timetable. The underlying principle is that, no matter what the unforeseen events can take place, the service has to be assured for the customer, with the further guarantee that the predicted 
frequency and punctuality are not significantly affected.

So, bearing in mind that unpredictable events can occur at any time, various demands, at different levels, are placed on these drivers, namely: the obligation to know all routes assured by the company, and an understanding of the vehicles and how they work.

Besides this, the total lack of planning for these drivers leads to a set of circumstances which regularly compromise rest periods or lunch and dinner periods, thus contributing to a multiplication of health problems, frequently associated with sleep or gastrointestinal problems. On the other hand, the precariousness of this function (commonly attributed to drivers at the beginning of their careers) is associated with the promises that it is just a period of transition aimed at evaluating the capacity to adapt and to acquire experience - until there is an opportunity to be integrated in a regular schedule team. In these conditions, the workers hardly express, at their workplace, the first signs referring to their physiological limits, which could thus endanger their health (Lacomblez, 2000).

Drivers' activity is, therefore, anchored on diverse specific conditions related to the prescribed work organization. But there are other conditions which equally should be considered and which take place in the context of where the service is rendered.

\section{3.- Methodology}

The method favoured by us to better understand the options and the priorities assumed by the drivers during their activity was the ergonomic work analysis. To put it forth we used: observations of the activity of various drivers, in real context; filming the activity; and interviews with these drivers, as well as certain of its colleagues - namely, the traffic controllers and the agents who coordinate the bus distributions.

Two case studies were carried out, corresponding to two paradigmatic situations of what characterizes the sector nowadays. In the first case we analyse the activity of drivers on a shared route, a situation which is becoming frequently more common as a result of the privatisation policy and the increase in the number of public transport operators in the nineties. In the second case we report on an analysis of drivers' activity on an exclusive suburban route. The objective inherent to this methodological choice consisted of understanding the activity and the options in which it takes place, as we are convinced that we would find arguments that would nourish the debate of the changes to be proposed, in order to give a new "whiff" to the use of public transportation.

\section{1.-First case study: analysis of driver's activity on a shared route}

The route under analysis, represented in figure 1, is a route shared by three companies (A, B and C) with different characteristics, which explains why the driver's objectives are distinctly different in each of these companies (see Table 1). In total, this route includes 72 stops, with the time prescribed to complete the route being 63 minutes. This means that, theoretically, the drivers have, between each stop, less than one minute for letting the passengers get on and off, for exchanging information, for selling tickets and for driving, which all together represents a very significant time constraint on the activity. This is the reason why these drivers consider the moments at the beginning and end of each route as being crucial, since whatever the delay in the services rendered, there will always be consequences on the punctuality of all following services. 


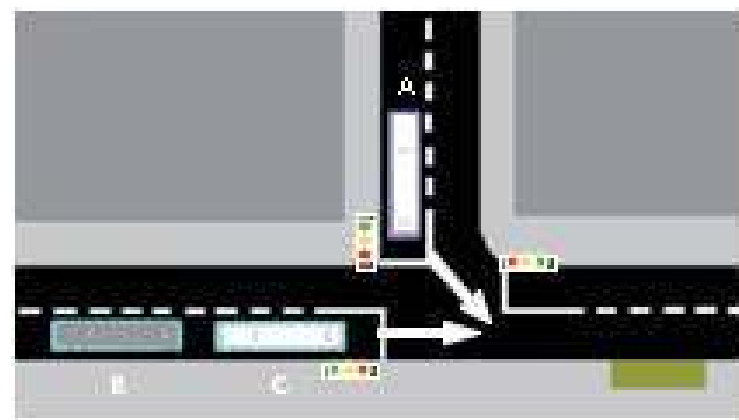

Fig. 1: Representation of the route shared by companies A, B and C

\begin{tabular}{|c|c|}
\hline Characteristics of the company & Objectives of drivers' activity \\
\hline A: Public company & $\begin{array}{l}\text { To ensure citizens' rights to mobility, } \\
\text { guaranteeing the respect for the norms of } \\
\text { frequency and continuity }\end{array}$ \\
\hline $\begin{array}{l}\text { B: Private company: the analysed route is } \\
\text { a concession of company A to company B. } \\
\text { Company A defines a number of kms per day and } \\
\text { pays company B a value per km. }\end{array}$ & $\begin{array}{l}\text { Objective centred on the predicted number of } \\
\mathrm{kms} \text { and on the timetable }\end{array}$ \\
\hline $\begin{array}{l}\text { Ticketing from company A, but work organization } \\
\text { as a responsibility of company B }\end{array}$ & \\
\hline C: Private company & $\begin{array}{c}\text { To transport the largest possible number of } \\
\text { passengers, since income achieved comes from } \\
\text { ticket sales }\end{array}$ \\
\hline
\end{tabular}

Table 1.- Characteristics of companies in the first study

As we can see in figure 1, up until a certain point the route is shared by companies B and C (the stops are strictly the same). But, after a certain point, the route became shared by all three companies.

How do the drivers respond to the objectives which regulate their activity, bearing in mind that the route is shared and the timetables are very similar to the drivers of the other companies? What strategies, therefore, are constructed?

\section{2.-The second case study: analysis of driver's activity on an exclusive route}

The second route under analysis is situated in a suburban context, and is used exclusively by only one private company, which has defined particular criteria to handle this route: only highly-experienced drivers, with a long service record in the company, drive this route, taking into consideration the existence of innumerable characteristic constraints.

In fact, driving this route is not easy: the road is very narrow and the route is situated in a warehouse zone, where at any given moment there are parked vehicles being loaded and unloaded. Drivers' experience is therefore fundamental, as it allows them to adjust their strategies and resolve the difficulties which they face, globally respecting the predicted timetable.

It is also worth mentioning that the interval between services is much greater in this case - about 30 minutes -, than in the case of urban routes, which regularity is quite superior.

The question is, then, to understand what options the drivers have in the carrying out of their activity, taking into account that the service they offer is less frequent but, even so, marked by diverse constraints which can put the respect for their timetable at risk. 


\section{4.- Results and discussion}

The analysis of the activity in real context allows us to observe that the strategies of competition that we can imagine within a shared route, take the form of collectively negotiated compromises, allowing each driver to reach his goals, but also a global regulation of service rendered to the users.

The drivers from company $\mathrm{C}$, for example, always start the route some minutes before those of company $\mathrm{B}$ do, which therefore allows them to gain a certain advantage in transporting more customers and in guaranteeing a satisfactory income. It seems important to mention that the drivers from company $\mathrm{B}$ are aware of this strategy developed by drivers from company $\mathrm{C}$ and participate in its functioning, by not over taking their buses and giving way in situations seen on the road. But they do it, because their respective objectives do not overlap.

Besides, when they are behind schedule, company B drivers, change their strategy, since one of their priorities consists of following the timetable as foreseen. Their main concern is, then, to catch up time, so that the criteria defined by the attribution of the concession are, thus, not put at risk.

On the other hand, the entrance of company A drivers on the route does not affect the compromise established by the drivers of companies $\mathrm{B}$ and $\mathrm{C}$, since the social objective inherent to the service they offer is, for them, clearly prior. In fact, the analyses of the activity of company A drivers showed that these also seek to ease the progress of the drivers from company $\mathrm{C}$ on the route.

This seems to correspond to a concrete expression of a collective regulation strategy that integrates and overtakes the challenges of an economic reality, which is of growing importance in the sector, without compromising citizens' right to transportation.

But this visible distance between the real and the prescribed also suggests that, in response to the challenges which face the sector, the options in terms of organization of drivers' work and the principles which regulate their activity cannot continue to be exclusively assumed as part of market logic (Cunha, 2005).

The analyses of the changes at work, and the values which justify privileged options, were particularly developed by the Département d'Ergologie at the Université de Aix-en-Provence, in what was designated as "ergological approach". This contribution has been decisive, as it allowed us to evolve in the reflexion prompted by the data collected in the two case studies.

Despite having its roots in another scientific tradition, the contribution of ergology in this research is intrinsically associated with an approach to the activity immersed in a world of knowledge, options, norms and values. But the heuristic character of this new theoretical contribution resulted mainly of the distinction established by ergology between market values (measurable and quantifiable) and values "without dimension" (non-quantifiable, which are associated to social rights, workers" rights and democratic deliberation) (Schwartz, 1996; Schwartz, \& Durrive, 2003).

In the tradition of activity ergonomics, the expression of different logics is noticeable in the nuance established between prescribed work and real work. The ergological approach has also contributed to a better comprehension of this research field, proposing the concepts of antecedent norms and renormalizations (the activity as a setting of negotiation space of the norms constructed by the subject, when facing the norms defined by others).

In the second study, the participation of workers in the debate on the type of values associated to their activity is particularly evident. As an example, it seems important to note that drivers frequently assume the decision of opening the doors, so passengers can get on and off the bus, away from the bus stops. So, as we noted, the time constraint is very significant; but, moreover, these drivers have a high risk of being penalized.

Despite being a private company, these options reveal that drivers seem to take more into account the irregularity of the service they offer, than potential income due to the transportation of more passengers. This leads us to admit that, similar to what happened in the first case study, this situation does 
not just describe a driver's casual choice, but it is more an attempt to renormalize his activity.

The activity appears, in this case study, as the context of a debate between antecedent norms and the needs of the customer. Even though this activity is regulated by market values, of profitability, drivers reorientate the service they render, considering other dimensions that the antecedent norms have not foreseen.

\section{Conclusion}

With the development of the urban areas and the widespread use of the private vehicle, strategies to increase the use of public transport have evolved.

In the case of the Metropolitan Area of Porto, the recent introduction of the Metro, and the progressive widening of its network, is causing a profound restructuring of the services offered by all public transport operators. Nowadays, the main goal is to abandon a strategy exclusively aimed at guaranteeing greater access to customers, and to start creating a new coordinated collective service with the whole of the operators, with the purpose of diminishing the weight of the use of the private vehicle.

To achieve such goals, the solution cannot be satisfied by measures such as the reconversion of each driver in "outside-the-rules-drivers". It would be more adequate to rethink the rules that regulate the workers' activity. After all, the central question is what margin are they given, as the main intervenient in this service relation, to manage the activity, knowing that they must correspond to the company objectives, and responding to the many varied requests of the customers?

The analyses of driver activity in two representative situations of the contexts in which they actually work, has shown us how the activity constitutes a favourable space for the redefinition of the orientation to be given to their activity.

The results obtained allow us therefore to recognize an indispensable contribution of the ergonomic work analysis, to the understanding of drivers' priorities and to the definition of an intervention on their working conditions. But it has also led us to start a debate around the objectives inherent to the services of public transport.

The studies developed enhanced the fact that it is in the activity that a decisive discussion on the sense and on the rendering a public service takes place (Orban, 2004). A driver who opens the doors to let passengers get on away from the place indicated as a bus stop (because he knows that the waiting time, until the arrival of the next bus, is long), is he committing a transgression of his antecedent norms? Or is this a sign that should lead to a debate on the values convoked in service rendering?

More important than adopting a position that penalises this type of strategy, as if this was a real transgression, it seems fundamental to rethink the work organization and the conditions that drivers face, to guarantee a quality service to the users.

Although the notion of "public service" has been assuming an increasing mercantile connotation, we admit that it is thanks to the renormalization work that the drivers make in the activity that the service they offer is, progressively, adapted to the real needs of the customers, and contributes to a new priorities hierarchy. This reinforces our conviction that the changes previewed to this sector cannot despise workers active participation.

The lack of consideration of the role played by the drivers in this sector - which is one of the most complex in terms of regulation time (Gauderer, \& Knauth, 2004) - could end up seriously compromising the project of conceiving a new path to encourage people to use public transport. 


\section{REFERENCING}

Cunha, L., \& Lacomblez, M. (2007). Market and regulation of general interest in the passenger land transport sector: a debate renewed by drivers' activity. @ctivités, 4 (1), pp. 141-148, http://www.activites.org/v4n1/ v4n1.pdf.

\section{REFERENCES}

ANTROP (2002). Linhas de orientação estratégica para o sector de transportes colectivos rodoviários de passageiros. Caracterização do sector e aspectos particulares. Edições ANTROP.

Cunha, L. (2005). Opções, Valores e estratégias: que contributos para outras racionalidades? Dissertação apresentada para a obtenção do grau de Mestre em Psicologia do Trabalho. Porto: Faculdade de Psicologia e de Ciências da Educação da Universidade do Porto.

Flageul-Caroly, S. (2001). Régulations individuelles et collectives de situations critiques dans un secteur de service: le guichet de la Poste. Dissertation présentée pour l'obtention du grade de Docteur de l'École Pratique des Hautes Études. École Pratique des Hautes Études: Laboratoire d'Ergonomie Physiologique et Cognitive.

Gadrey, J. (1996). L'économie des services. Paris: Éditions la Découverte.

Gauderer, P. C., \& Knauth, P. (2004). Pilot study with individualized duty rotas in public local transport. In Temps et activités de travail - Hommage à Yvon Quéinnec. Le Travail Humain, 67 (1), 87-100.

INOFOR (2000). O sector de transportes em Portugal. Lisboa.

Lacomblez, M. (2000). Factores psicossociais associados aos riscos emergentes. Riscos emergentes da nova organização do trabalho. Lisboa: IDICT.

Noulin, M. (1995). Analyser l'activité et/ou comprendre le travail. Actes du Séminaire DESUP/DESS (7-10). Paris: Université Paris 1, 29 mai - 2 juin.

Orban, E. (2004). Service Public! Individu, marché et intérêt public. Paris: Éditions Syllepse.

Schwartz, Y. (1996). Ergonomie, philosophie et exterritorialité. In F. Daniellou (Ed.), L'ergonomie en quête de ses principes. Débats épistémologiques (pp. 141-182). Toulouse: Octarès Éditions.

Schwartz, Y., \& Durrive, L. (Eds.) (2003). Travail \& Ergologie. Entretiens sur l'activité humaine. Toulouse: Octarès Éditions.

\section{RÉSUMÉ}

Cette étude analyse l'activité de travail de conducteurs du secteur des transports en commun de passagers dans la zone métropolitaine de Porto. Elle tient compte des évolutions qui font suite à une politique de privatisation et, notamment, à des changements survenus au niveau de l'organisation du travail et des objectifs qui régulent cette activité. Deux cas ont été l'objet d'une attention particulière. Dans le premier cas, un parcours de bus a été sélectionné en raison du fait qu'il est exploité par trois entreprises: une entreprise publique; une autre contrôlée par l'entreprise publique parce qu'une concession lui a été attribuée; et une troisième entreprise privée. Dans le second cas, l'analyse a couvert un parcours assuré par une seule entreprise privée. Les résultats de cette recherche suggèrent que les politiques des entreprises du secteur se basent, en général, essentiellement sur des options déterminées par le marché. Toutefois, il semble que les conducteurs recherchent un équilibre entre ces options et des choix et solutions qui leurs sont propres, mais ont leur source dans le champ des valeurs sans dimension. La contribution de l'ergologie enrichit la réflexion concernant les stratégies et les renormalisations que les travailleurs effectuent, au quotidien, de manière à établir des compromis opératoires susceptibles de rendre 
possible la gestion combinée des objectifs de l'activité et les besoins réels des usagers.

MoTS CLÉ:

Théorie de l'activité, Changements, Activité du conducteur, Approche ergologique, Valeurs.

\section{RESUMEN}

Mercado y regulación del interés general en el sector del transporte vial de pasajeros: un debate renovado por la actividad de los conductores. Este estudioanalizalaactividaddetrabajodelosconductoresdemediosdetransporte público de la región metropolitana de Oporto. Considera las evoluciones que ha generado las políticas de privatización. Es decir, los cambios en el plano de la organización del trabajo y de los objetivos que regulan esta actividad. Se ha prestado particular atención a dos casos en especial. En el primer caso, se seleccionó un recorrido de autobús operado por tres empresas: una empresa del Estado, otra, en concesión, que opera bajo supervisión de esa misma empresa del Estado, y una última empresa privada. En el segundo caso, el recorrido estaba en manos solamente de una empresa privada. Los resultados finales de esta investigación sugieren que las políticas de las empresas están generalmente basadas en criterios orientados por la lógica del mercado. Por otro lado, los conductores intentan equilibrar estos criterios realizando sus propias elecciones y soluciones basadas sobre valores sin dimensión. La contribución de la ergología enriqueció la reflexión sobre las estrategias y la renormalización que los trabajadores realizan día a día, logrando establecer compromisos operativos que permiten la gestión de los objetivos de la actividad y de las necesidades reales de los usuarios.

Palabras-clave

Teoría de la actividad, Cambios, Actividad del conductor, Abordaje ergológica, Valores 